\title{
The Impact of Technological Developments on Remote Working: Insights from the Polish Managers' Perspective
}

\author{
Maria Urbaniec ${ }^{1, *(\mathbb{D}}$, Agnieszka Małkowska ${ }^{2} \mathbb{D}$ and Hanna Włodarkiewicz-Klimek ${ }^{3, *}$ \\ 1 Department of Entrepreneurship and Innovation, Cracow University of Economics, Rakowicka 27, \\ 31-510 Krakow, Poland \\ 2 Department of Real Estate and Investment Economics, Cracow University of Economics, Rakowicka 27, \\ 31-510 Krakow, Poland; malkowsa@uek.krakow.pl \\ 3 Institute for Management and Information Systems, Poznan University of Technology, Rychlewskiego 2, \\ 60-965 Poznań, Poland \\ * Correspondence: maria.urbaniec@uek.krakow.pl (M.U.); \\ hanna.wlodarkiewicz-klimek@put.poznan.pl (H.W.-K.)
}

check for updates

Citation: Urbaniec, M.; Małkowska, A.; Włodarkiewicz-Klimek, H. The Impact of Technological Developments on Remote Working Insights from the Polish Managers' Perspective. Sustainability 2022, 14 , 552. https://doi.org/10.3390/ su14010552

Academic Editors: Won-Moo Hur and Yuhyung Shin

Received: 18 December 2021

Accepted: 31 December 2021

Published: 5 January 2022

Publisher's Note: MDPI stays neutral with regard to jurisdictional claims in published maps and institutional affiliations.

Copyright: (C) 2022 by the authors. Licensee MDPI, Basel, Switzerland. This article is an open access article distributed under the terms and conditions of the Creative Commons Attribution (CC BY) license (https:// creativecommons.org/licenses/by/ $4.0 /)$.

\begin{abstract}
Stay at home" orders during the COVID-19 pandemic radically changed the day-today operations of many organizations and moved employees from offices to homes. The sudden crisis forced companies to reformulate their operations. Enabling employees to work from home has become a necessity for both business continuity and survival. The unexpected crisis has also proved to be beneficial for some aspects of economic activity. This research focuses on identifying and measuring the benefits of and barriers to remote work from an organizational perspective, as perceived by managerial staff in Poland. We investigate the factors that influence the assessment of the scale of benefits of and barriers to remote working. The study examines the impact of various factors on the benefits of and barriers to remote working, such as a company's previous experience with remote working, the support provided to employees by the company, the monitoring of remote working effects, and the implementation of new IT tools. These results suggest that the way the company and employees are managed in a crisis, the approach of superiors to the evaluation and control of effects on work, and the adaptation of support to the real needs of employees, all play fundamental roles. The factors examined that influence the perceived benefits of or barriers to remote working from an organization's perspective contribute to adoption theory.
\end{abstract}

Keywords: remote working; benefits; barriers; learning organization; technological developments; discipline

\section{Introduction}

The development of flexible work arrangements had already been the subject of growing research interest for some time prior to the COVID-19 pandemic [1-4]. The intensive development of communications technology and mobile devices reduced the need to provide work in a fixed workplace and created favorable circumstances in this regard. In addition, the proliferation of flexible work arrangements was driven by employers' recognition of the potential benefits, such as reduced costs and increased economic outcomes, and by their response to employees' needs and preferences. Globalization processes and increasing market competition have also played significant roles in the introduction of new business models and work models [5].

Remote working is one of the flexible forms of work arrangements used to produce and deliver work output. Its applications can appear in different forms and be described with various terms, such as telework, telecommuting, ICT-based mobile work, mobile eWork, mobile virtual work, homeworking, or home-based work. Although the literature distinguishes between and classifies different forms of remote work [6], it usually refers to work outside an employer's premises, supported by ICT technology tools. 
Prior to the COVID-19 pandemic, remote work in EU countries was done occasionally and by relatively few employees. According to a 2020 EC report [7], in 2019 only $5.4 \%$ of employees in the EU-27 usually worked from home, while 9\% worked from home at least sometimes. Polish workers ranked slightly below the EU-27 average in 2019 for those who usually worked from home (4.6\% of employees) and above the average for those who sometimes worked from home $(9.8 \%)$ [8].

The diffusion of remote working as a form of alternative agreed working relationships between employer and employee varied across sectors, occupations, and work roles. Adopting this form of work required the employer to provide adequate technical support, transfer a large measure of autonomy to the employee, and overcome the absence of direct control. Therefore, remote working was often seen as a privilege for managers and sufficiently long-tenured professionals, accompanied by an established trust between employer and employee [9]. From an industry perspective, it was the ICT sector, knowledge-intensive business services, the education sector, and publishing-related activities that enjoyed a much higher degree of remote work than other types of work [7]. The ICT sector, in particular, has been and remains an example of progress and innovation in this field. On the one hand, it develops technologies that change work and socio-economic life; on the other hand, it independently and pioneeringly applies its inventions to employment and work organization. Simultaneously, these technologies and practices are spreading to other sectors [10].

The COVID-19 pandemic changed these perspectives radically. Working from home has ceased to be a privilege and has often become a necessity. Government recommendations, subsequent lockdowns, and the determination to maintain business continuity while ensuring employee safety have forced many companies to implement remote work to the greatest possible degree. Although teleworking was already well known as an effective way to ensure operational continuity for businesses in complex disaster environments (primarily during natural disasters) [11], until the pandemic a number of companies had very limited experience with remote work. This observation applies to both the private and public sectors, although it is more applicable to the latter. Remote working or hybrid-working have begun to be used on a widespread scale even by entities that were not adequately prepared for such arrangements, either technically or organizationally. However, the prolonged period of the pandemic, after the first months of shock, resulted in successive adaptation of both employees and employers. Companies have accelerated the digitalization of their business processes and learned to operate effectively in the new conditions. In addition, employees and employers have seen the benefits of remote working, even while barriers still exist.

Our research grew out of the need to reassess the benefits of and barriers to remote working, focusing on the context of its spread in response to the COVID-19 pandemic. We focus primarily on the benefits and barriers from the organizational side, as seen through the eyes of managers. As Pérez et al. [12] argue, the managers' perspective provides an important framework for studying remote work as a human resources innovation and considering its adoption by organizations. Schofield and Peel [13] stress that managerial approval is critical in the uptake and success of teleworking. Thus, the main objective of our research is to identify the benefits of and barriers to remote working, including the managerial and organizational perspectives. Our survey answers the following questions: (1) what are the benefits of and barriers to remote working in Polish companies, and (2) what factors increase the benefits of or reduce the barriers to remote working? In particular, we aim to find out whether the nature and intensity of remote working in an organization before the COVID-19 pandemic has affected current outcomes. We also examine whether organizational support, the implementation of new technological tools, and the monitoring of remote working actually increase benefits and reduce perceived barriers to remote working, as assessed by managers.

Our research is part of a broad discussion of new technologies and their impacts on work, employment, human resources management, and organizational performance in 
the era of the COVID-19 pandemic and beyond [2]. In particular, but not exclusively, it contributes to research on the themes of control of, surveillance of [14], and support for employees working from home $[15,16]$. Access to new technological tools reduces barriers to remote working, while job monitoring (not necessarily tailored to new forms of work) increases them. Moreover, the benefits of working from home appear to be higher for firms that had less experience with this form of work before the pandemic, relative to those firms that worked remotely on a larger scale. In turn, greater experience with remote working before COVID-19 lowers the barriers to this form of work during the pandemic.

The article consists of four sections. The first section includes a literature review on the benefits and barriers of remote working. The second section presents the sources and characteristics of the data and methods used. The third section provides the results and a discussion of the research, and the fourth section presents our final conclusions.

\section{Literature Review}

Although remote work is described in various terms, and its forms vary in detail, "teleworking" and "telecommuting" are the most general and commonly used terms [17]. The origins of remote work can be traced back to Jack Nills $[18,19]$, who introduced the terms "telecommuting" and "telework" and initially popularized the idea of "moving the work to the worker" as a remedy for traffic congestion that resulted from workers going back and forth between home and work, and as a way to reduce energy consumption [20,21]. Since then, remote work has gained growing interest from scholars. Important threads of research in the field include the benefits and pitfalls of remote work, as well as the driving forces behind it [17,22-25].

In general, the literature provides a set of factors and conditions affecting the adoption and effectiveness of remote work. They are listed below [26-29]:

- the employee (in terms of individual personal characteristics, attitudes, values, and needs, as well as family circumstances and the physical conditions for working at home);

- the nature of the work (job "teleworkability", including highly autonomous and complex jobs performed by professionals and less autonomous work that can be done at home and be easily audited and managed remotely);

- the organization and its culture (whether remote working fits into the organization and its strategy, goals, and control mechanisms, and how supportive the organizational culture is);

- the supervisor's management style (e.g., the willingness of supervisors to agree to employees working from home, appropriate levels of trust between supervisors and employees, the ability to extend autonomy and reduce direct control of work in favor of alternatives that are often indirect, control mechanisms, providing support to the employee); and

- the technological capacities (e.g., availability of technological solutions and tools, employee technology support, data security).

As Clark [30] points out, telecommuting is primarily for experienced and highperforming employees performing work that does not require constant interaction with co-workers, close supervision, or frequent assignment of tasks. Desirable characteristics teleworkers may possess include self-reliance, strong motivation, focus, self-discipline, and being well-organized [17]. An important driver compelling companies to embrace telework adoption is the attitude of managers towards telework and its challenges [31]. Thus, one of the most important factors for the effective application of teleworking solutions is the support delivered by managers and supervisors [32,33]. Similarly, due to the greater dependence of remote workers on technology, technical assistance is an important condition underpinning favorable outcomes of teleworking [33].

From the early days of remote working in business and academia to the present, one of the primary research threads has been the benefits of and barriers to this form of working. Picking up this thread in subsequent studies is important, as some of the 
effects observed are ambiguous and depend on individual employee-employer-family circumstances and the motives behind choosing to work remotely. The best recent example is the COVID-19 pandemic, which has unsettled previous assumptions regarding remote working. It was generally believed that the decision to work remotely should be voluntary, and the employer should have the capacity to reap benefits from remote work.

Traditionally, the benefits and disadvantages of remote working have been discussed in relation to three areas: the environment/society, the employee. and the organization $[34,35]$. Commonly stated environmental and social benefits are those resulting from a reduction in car traffic and less strain on the transportation infrastructure. The possibility of remote working also has a positive impact on the labor market by creating alternative employment opportunities for people who have been excluded due to disability or other special needs [24]. Nevertheless, remote working also carries serious social challenges, including the risk of creating a disconnected society by cutting people off and isolating them from each other [23], which becomes an even more pressing problem in light of repeated lockdowns and the need to maintain social distancing.

The perspective most often examined in the literature is that of the employee. Researchers have identified numerous benefits and drawbacks of teleworking for individuals. Some may appear contradictory, as a result of individual employees' situations, family circumstances, the nature of the work, and the specific characteristics of the organization [27]. Examples of advantages of telework for employees are time-space flexibility, enhanced work autonomy, more favorable working conditions, time and cost savings, fewer distractions, less stress, and increased time for family and social responsibilities. Such benefits can result in greater job satisfaction, improved work-life balance, and greater wellbeing $[22,23,36]$. However, not all of these benefits are guaranteed. The home environment is full of distractions, and conditions at home are not necessarily more conducive to work than conditions in the office; multiple roles often overlap (work, family, and social), the boundaries between work and non-work time blur, feelings of isolation and loneliness may arise, longer work hours and increased workloads may occur, time management issues may develop, and concerns about job insecurity may increase $[22,23,25]$. These problems may sound familiar to the multitude of people who are forced to work remotely during lockdown; from an individual perspective, the benefits of working from home do not necessarily outweigh the drawbacks. The impact of remote working on job satisfaction [37-41], work-life balance [42-47], employee wellbeing [48-50], and work-family conflicts [17,51-54] are still developing areas of research, and indeed have lost none of their relevance in the light of the COVID-19 pandemic. On the contrary, the scholarly work carried out during the pandemic bears out previous findings and extends them in the context of the new reality [4].

The importance of research on the effects of remote working for employees is also compelling with respect to the benefits for organizations that implement remote working models. For example, there is empirical evidence that higher job satisfaction translates into less turnover and increased work performance [55]. While employee wellbeing is arguably one of the motives for employers to implement and expand teleworking, the main incentive, according to Baruch [36], is cost-effectiveness, i.e., reducing costs. Indeed, as many employees working from home during the COVID-19 pandemic have experienced, teleworking done in the absence of alternatives simply shifted some costs to the employee. Likewise, the benefits and drawbacks of remote working are not indisputable for employers. For organizations, the possible benefits of remote working, often mentioned in the literature, include higher productivity and work quality, less absenteeism, greater loyalty, increased commitment and morale, reduced office space, simplified recruitment, the retention of skilled employees, and lower unit work costs [36,56].

As mentioned above, achieving a certain range of benefits is determined by a number of factors, and it is far from straightforward. For example, an increase in organizational commitment can occur due to support provided to employees in dealing with family problems faced while teleworking [57]. Implementing and expanding teleworking programs 
presents companies with a number of challenges. The main ones highlighted in the literature include formal preparation on the part of the organization (in terms of policies, objectives, and procedures), the creation of an appropriate infrastructure, maintenance of IT tools and equipment (e.g., ensuring secure access to data and systems, repairing and maintaining equipment located in employees' homes), re-modelling processes, designing work, creating rules and communication paths, developing methods for monitoring and measuring performance, and preparing managers and employees to work in the new environment [58].

The benefits and challenges of remote working, as well as the adaptation factors, grew out of observations and research conducted before the outbreak of the COVID-19 pandemic. While they remain relevant, the conditions under which remote working took place were extremely different. During the COVID-19 pandemic, people were more or less forced to work from home and endure lockdowns, working overnight, full-time and in total physical isolation. There was little or no time for organizations, management, and employees to prepare, no clear prospects for the future, and enormous amounts of stress and uncertainty [59]. Interestingly, despite developing interest in remote working, it was a new experience for most employees and employers. Given these particular circumstances, and the fact that remote working has now become a requirement and a necessity rather than a relatively voluntary choice or even a form of reward and a sign of trust for the employee, Wang et al. [4] emphasize the strong need to review previous findings and conduct new research on remote working in the context of COVID-19. Our research responds to this demand. We seek to assess the benefits and barriers to remote working as perceived by executives and the impact of such key factors as employee support, implementation of new technological tools, and monitoring remote work on the scale of perceived benefits and barriers. The types of factors examined include those that are important for a company's interests. We consider the lack of preparation and experience with remote working, and its relatively low prevalence, before the COVID-19 pandemic.

\section{Data and Methods}

Our survey was conducted among the managerial staff of companies representing various manufacturing and service sectors in Poland. The respondents were both private and public sector entities. In terms of enterprise size, measured by the number of employees, the sample included a full cross-section of enterprises, from those with fewer than 10 employees to companies with upwards of 250 employees. The geographic scope of companies' activities included local/regional markets, domestic markets, and international markets.

The data collection was conducted between May and July 2020 using the CAWI (Computer-Assisted Web Interview) technique. The research sample totaled 230 respondents. The questionnaire was addressed to managers with at least several years of experience in their respective companies. The gender structure was slightly more male (about $55 \%$ ) than female. The research sample is described in Table 1.

Table 1. Profile of respondents.

\begin{tabular}{ccc}
\hline Criteria & Sub-Criteria & Frequency (\%) \\
\hline Gender & Man & 55.22 \\
& Woman & 44.78 \\
Position held in the company & Company owner/partner & 2.17 \\
& President/Member of the & 8.79 \\
& Management Board & 44.78 \\
Total seniority & Director & 44.35 \\
\hline
\end{tabular}

Source: authors' own study. 


\subsection{Measuring the Benefits of and Barriers to Remote Working-Methodological Remarks}

The survey was focused primarily on identifying the benefits and barriers to remote working during the COVID-19 pandemic; accordingly, respondents were asked to answer two questions:

- do you recognize the positive effects of remote working in your company?

- do you recognize specific difficulties in your company transitioning to remote working?

For both questions, the questionnaire contained a closed set of statements (see Appendix A), to which the respondents were asked to provide answers according to the 5-point Likert scale. The benefits of remote working include advantage for both the company and employees. The direct benefits for companies include investments in IT infrastructure, the introduction of new tools and solutions for remote work, and moving part of a company's activities online. Indirect benefits include improved flexibility of organizational structure, diversification of products and services, increased expenditure on research and development, and cooperation with external entities on innovation. The benefits for employees include the development of digital skills through company-organized training, the creation of new jobs supported by remote work, and the ability to balance professional work more easily with household duties. Barriers to remote work include technical hurdles, such as the lack of an adequate IT infrastructure and hardware and lack of IT funding; organizational barriers, such as access to a company's documents in electronic form, the lack of appropriate procedures and guidelines, and internal communication difficulties; and social barriers, including the reluctance of management and employees to engage in new forms of work, the lack of digital skills, difficulties in motivation, and the maintenance of employee efficiency.

The rapid uptake of remote working may be beneficial for those employers and employees seeking greater workplace flexibility. The most widespread benefits of remote working are building a flexible organization and moving some business activities online. The least common benefits, while still being perceived as beneficial by $70-80 \%$ of the respondents, include the development of investment in IT infrastructure and solutions for remote working, as well as increased work efficiency.

Overall, the respondents believed the benefits of remote work decidedly outweigh the barriers. The most frequently observed barriers in the respondents' companies include lack of funds for investments, the need to develop instructions for employees, and difficulties in maintaining employee efficiency. The least cited barriers include the reluctance of management and employees to perform remote work. Full statistics for respondents' ratings are provided in Appendix A.

Two indices were constructed based on the respondents' ratings: the remote work benefits index and the remote work barriers index. The methodology used for building the indexes was as follows:

1. We conducted a Principal Components Analysis (PCA) to reduce the initial number of index-eligible variables. The PCA for the statements reflecting the benefits of remote working showed eigenvalues for the first five components as follows: $2.4034 ; 1.0159$; $1.0032 ; 0.9634$, and 0.6789 . The Kaiser criterion indicates three principal components, which explain $78.15 \%$ of the total variance, with the first component explaining $57.76 \%$, the second $10.32 \%$ and the third $10.06 \%$ (see Table 2 ).

Table 2. Benefits of remote work-PCA results.

\begin{tabular}{ccccc}
\hline No. & Parameter & PC1(A) & PC2(A) & PC3(A) \\
\hline A1 & Building a flexible/learning organization & -0.003 & 0.86 & -0.104 \\
\hline A2 & Diversification of services or products & 0.808 & 0.139 & 0.225 \\
\hline A3 & $\begin{array}{c}\text { Investments in IT infrastructure and } \\
\text { solutions for remote working }\end{array}$ & 0.693 & -0.272 & -0.301 \\
\hline A4 & Moving some business activities online & -0.126 & -0.171 & 0.871 \\
\hline
\end{tabular}


Table 2. Cont.

\begin{tabular}{|c|c|c|c|c|}
\hline No. & Parameter & PC1(A) & PC2(A) & РС3(A) \\
\hline A5 & Increased R\&D spending & 0.583 & 0.386 & 0.201 \\
\hline A6 & $\begin{array}{l}\text { Cooperating with external entities } \\
\text { on innovation }\end{array}$ & 0.912 & -0.041 & 0.002 \\
\hline A7 & $\begin{array}{l}\text { Training for employees in advanced } \\
\text { digital technologies }\end{array}$ & 0.889 & 0.07 & 0.081 \\
\hline A8 & $\begin{array}{c}\text { Creating new jobs based on remote } \\
\text { working model }\end{array}$ & 0.958 & -0.067 & -0.031 \\
\hline A9 & Increasing work efficiency & 0.95 & -0.073 & -0.04 \\
\hline A10 & $\begin{array}{l}\text { Possibility to combine professional work } \\
\text { with household commitments }\end{array}$ & 0.919 & -0.065 & -0.043 \\
\hline & \% Explained Variance & $57.76 \%$ & $10.32 \%$ & $10.06 \%$ \\
\hline & Cumulative & $57.76 \%$ & $68.08 \%$ & $78.15 \%$ \\
\hline
\end{tabular}

The eigenvalues for the first five principal components of the barriers of remote work were: $3.2426 ; 1.3998 ; 0.6629 ; 0.5966$, and 0.4241 . The Kaiser criterion thus indicates two components, which explain a total of $89.1 \%$ of the total variance. The first component explains $75.1 \%$ of the variance while the second component explains $14 \%$ (see Table 3 ).

Table 3. Barriers to remote working-PCA results.

\begin{tabular}{|c|c|c|c|}
\hline No. & Parameter & PC1(B) & PC2(B) \\
\hline B1 & Insufficient IT infrastructure & 0.832 & -0.444 \\
\hline B2 & Shortage or lack of computer hardware & 0.845 & -0.314 \\
\hline B3 & $\begin{array}{l}\text { Lack of ability to perform certain duties } \\
\text { remotely due to limited access to } \\
\text { company documents }\end{array}$ & 0.961 & -0.004 \\
\hline B4 & $\begin{array}{l}\text { No possibility to work remotely at } \\
\text { some workplaces }\end{array}$ & 0.952 & 0.028 \\
\hline B5 & No safety procedures & 0.943 & 0.047 \\
\hline B6 & Lack of or limited funds for investments & 0.265 & -0.924 \\
\hline B7 & $\begin{array}{l}\text { The need to prepare instructions } \\
\text { for employees }\end{array}$ & 0.576 & -0.669 \\
\hline B8 & $\begin{array}{l}\text { Lack of transparency in terms of work } \\
\text { and progress }\end{array}$ & 0.873 & 0.086 \\
\hline B9 & $\begin{array}{l}\text { Reluctance of managers or team leaders } \\
\text { to work remotely }\end{array}$ & 0.972 & 0.041 \\
\hline B10 & $\begin{array}{l}\text { Reluctance of employees to } \\
\text { work remotely }\end{array}$ & 0.932 & -0.009 \\
\hline B11 & $\begin{array}{l}\text { Difficulties in maintaining } \\
\text { employee efficiency }\end{array}$ & 0.9 & 0.325 \\
\hline B12 & $\begin{array}{l}\text { Decrease in employee motivation } \\
\text { and commitment }\end{array}$ & 0.933 & 0.295 \\
\hline B13 & Employees' lack sufficient digital skills & 0.933 & 0.371 \\
\hline B14 & Internal communication challenges & 0.927 & 0.292 \\
\hline & \% Explained variance & $75.1 \%$ & $14 \%$ \\
\hline & Cumulative & $75.1 \%$ & $89.1 \%$ \\
\hline
\end{tabular}


2. Based on the results of the PCA, only the variables forming the first components, PC1(A) and PC1(B), were used to construct the remote work benefit index and the remote work barrier index, respectively (see Appendix A). Thus, benefits No. A1 and A4 and barriers No. B5 and B6 were omitted. Both synthetic measures were created in the same way. Each possible answer was assigned a numerical value: "definitely not" - 0 ; "rather not" - 1; "hard to say"-2; "rather yes"-3; "definitely yes"-4. The numerical values of the remote work benefit index are expressed by a number between 0 and 32 (based on 8 statements), and the synthetic measure of the remote work barrier index is expressed by a number between 0 and 48 (based on 12 statements). The higher the numerical score, the greater the difficulty/benefit of working remotely, according to respondents.

\subsection{Estimation Strategy and Characteristics of the Variables}

To empirically test the impact of remote working experience before the COVID-19 pandemic and remote working arrangements on the scale of benefits of and barriers to remote working, a study was conducted using a linear regression model. In the first model $(\bmod 1)$, the dependent variable is the remote work benefit index (BI1), and in the second model $(\bmod 2)$, the dependent variable is the remote work barrier index (BI2). The same set of dependent variables was used in both models, where the experience with remote work before the pandemic is reflected by the pre-COVID-19 variable, and the organization of remote work in the company during the pandemic is characterized by a set of binary variables: Support, Monitoring, and Technology. In addition, the model includes a set of control variables that characterize both the respondents (see Table 1) and the entities they represent (see Table 4).

Table 4. Characteristics of the independent variables used in the analysis.

\begin{tabular}{|c|c|c|c|}
\hline Variable & \multicolumn{2}{|c|}{ Description } & Frequency \\
\hline \multirow{4}{*}{ Employees } & \multirow{4}{*}{ The size of workforce } & under 10 employees & 5.65 \\
\hline & & 10-49 employees & 23.91 \\
\hline & & 50-249 employees & 63.48 \\
\hline & & over 250 employees & 6.96 \\
\hline \multirow{2}{*}{ Profile } & \multirow{2}{*}{ Company sector } & manufacturing companies & 28.45 \\
\hline & & service companies & 71.55 \\
\hline \multirow{2}{*}{ Ownership } & \multirow{2}{*}{ Form of company ownership } & Public & 27.65 \\
\hline & & Private & 72.35 \\
\hline \multirow{3}{*}{ Area } & \multirow{3}{*}{$\begin{array}{c}\text { The scope of the company's } \\
\text { activities }\end{array}$} & Local/regional market & 26.95 \\
\hline & & Domestic market & 44.35 \\
\hline & & International market & 28.70 \\
\hline \multirow{4}{*}{ Pre-COVID-19 } & The scale/experience of & & \\
\hline & remote working in the & Small-scale & 38.26 \\
\hline & company before the & Mid-scale & 61.74 \\
\hline & COVID-19 pandemic & & \\
\hline \multirow{3}{*}{ Remote-COVID-19 } & Percentage of company & up to $20 \%$ & 36.09 \\
\hline & employees working remotely & $21 \%-60 \%$ & 45.21 \\
\hline & during COVID-19 & over $60 \%$ & 18.70 \\
\hline \multirow{4}{*}{ Support } & Whether the company & & \\
\hline & supports its employees in & No & 39.13 \\
\hline & remote working on a daily & Yes & 60.87 \\
\hline & bas1s & & \\
\hline \multirow{2}{*}{ Monitoring } & \multirow{2}{*}{$\begin{array}{l}\text { Whether the company } \\
\text { monitors the effects of } \\
\text { remote working }\end{array}$} & No & 46.09 \\
\hline & & Yes & 53.91 \\
\hline \multirow[b]{2}{*}{ Technology } & \multirow{2}{*}{$\begin{array}{l}\text { Whether the company is } \\
\text { introducing new tools for } \\
\text { remote working }\end{array}$} & No & 46.09 \\
\hline & & Yes & 53.91 \\
\hline
\end{tabular}

Source: authors' own study. 
The regression model takes the following form:

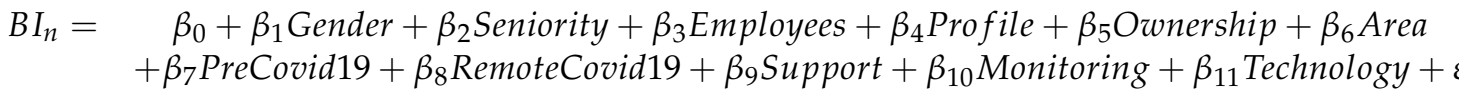

where $B I_{n}$ denotes the dependent variables BI1 and BI2 (benefit and barrier indexes), Gender denotes the sex of the respondent, Seniority describes the length of the respondent's work experience, Employees concerns the number of company employees, Profile distinguishes between service companies and manufacturing companies, Ownership indicates the public and private entities, Area denotes the extent of the market in which the company operates, PreCovid19 refers to the company's experience in remote work before the COVID-19 pandemic, RemoteCovid19 reflects the scale of remote work at the company during the COVID-19 pandemic, Support indicates whether employees receive any kind of help from the company in remote work, Monitoring shows whether the company is monitoring the effects of remote working, Technology reveals whether the company has implemented new tools to assist with remote working, $\varepsilon$ is the error term, and $\beta_{0}, \ldots, \beta_{6}$ are the parameters of the model.

\section{Results and Discussion}

We examined the influence of differentiated factors on the level of benefits of remote working. We concluded that, according to the results of the multiple linear regression model, the significant $(p<0.05)$ independent predictors of the level of benefits of remote working are seniority, company size, industry, operational scope, intensity of remote working before COVID-19, number of employees working from home during the pandemic, and implementation of new technological tools for remote working in the company (see Table 5).

Table 5. Benefits of remote working, regression results.

\begin{tabular}{|c|c|c|c|c|c|}
\hline \multicolumn{2}{|r|}{ Variables } & \multirow{3}{*}{$\begin{array}{c}\text { Parameter } \\
\text { ref. } \\
-0.027\end{array}$} & \multicolumn{2}{|c|}{$95 \%$ CI } & \multirow{3}{*}{$\begin{array}{c}p \\
0.959\end{array}$} \\
\hline \multirow{2}{*}{ Gender } & Man & & & & \\
\hline & Woman & & -1.06 & 1.006 & \\
\hline \multirow{2}{*}{ Seniority } & 6-15 years & ref. & & & \\
\hline & over 15 years & 1.504 & 0.194 & 2.814 & $0.026 *$ \\
\hline \multirow{3}{*}{ Employees } & under 50 employees & ref. & & & \\
\hline & 50-249 employees & 3.356 & 1.967 & 4.745 & $<0.001 *$ \\
\hline & over 250 employees & 4.509 & 1.912 & 7.107 & $0.001 *$ \\
\hline \multirow[b]{2}{*}{ Profile } & service companies & ref. & & & \\
\hline & manufacturing companies & -2.392 & -4.116 & -0.668 & $0.007 *$ \\
\hline \multirow{2}{*}{ Ownership } & Private & ref. & & & \\
\hline & Public & 2.255 & -0.77 & 5.28 & 0.146 \\
\hline \multirow{3}{*}{ Area } & Local/regional market & ref. & & & \\
\hline & Domestic market & 6.849 & 4.238 & 9.461 & $<0.001$ * \\
\hline & International market & 5.665 & 2.835 & 8.495 & $<0.001$ * \\
\hline \multirow{2}{*}{ Pre-COVID-19 } & Small-scale & ref. & & & \\
\hline & Mid-scale & -6.078 & -7.69 & -4.466 & $<0.001 *$ \\
\hline \multirow{3}{*}{$\begin{array}{c}\text { Remote-COVID- } \\
19\end{array}$} & up to $20 \%$ & ref. & & & \\
\hline & $21 \%-60 \%$ & 0.207 & -1.269 & 1.682 & 0.784 \\
\hline & Over $60 \%$ & -6.18 & -7.8 & -4.56 & $<0.001$ * \\
\hline \multirow{2}{*}{ Support } & No & ref. & & & \\
\hline & Yes & -1.763 & -3.773 & 0.246 & 0.087 \\
\hline \multirow{2}{*}{ Monitoring } & No & ref. & & & \\
\hline & Yes & -1.763 & -3.773 & 0.246 & 0.087 \\
\hline \multirow{2}{*}{ Technology } & No & ref. & & & \\
\hline & Yes & -5.198 & -8.656 & -1.739 & $0.004 *$ \\
\hline
\end{tabular}

Although the literature suggests that women favor remote work more than men [20], in our study the gender of the respondent did not influence the assessment of the bene- 
fits or drawbacks of working from home. These results are in line with the findings of Nakrošiene et al. [60], who found that women were less likely to perceive the advantages of teleworking, although the regression coefficient did not reach significance.

Executives with more seniority (i.e., with more than 15 years' experience) rated the benefits gained by the company from working remotely higher than did those with less seniority. The regression parameter is 1.504, thus raising the level of benefits from remote working by an average of 1.504 points in relation to executives with seniority of 6-15 years. This finding falls within the discussion of the role of experience in the use of information and decision-making by practicing managers. Experience has been proven to be an important determinant of managerial behavior for relatively non-programmed decisions [61], and seniority is used in the literature as a proxy measure for predictors of the adoption of telework [3,62]. In new and crisis conditions, such as the pandemic, longer managerial experience makes it easier to cope with the unknown and to view emerging opportunities more positively.

The size of the respondent's company also influenced their assessment of the benefits of remote working. For companies with between 50 and 249 employees, the regression parameter is 3.356 , raising the level of benefits of remote working by an average of 3.356 points over employment of less than 50 people. The effect is even stronger for larger companies with more than 250 employees and is consistent with the research-supported observation that larger companies show better adoption of new technologies [63,64], which are key to effective remote working. However, the impact of company's size on the adaption and diffusion of teleworking in the company is not straightforward. For example, Pérez et al. [12] confirmed that the potential for teleworking is influenced by, among other things, the company's use of information and communication technologies, its degree of innovation, and its size. However, the effect of firm size on the diffusion of remote work within a firm was negative when compared to our study, meaning that small companies tend to adopt telework more than their large counterparts. This stands in contrast to our findings, where firm size is positively correlated with the perceived benefits of remote working. Nevertheless, further research has not confirmed that firm size is a differentiating factor between teleworking adopters and non-adopters [65].

Operating a company in the industrial sector lowers the level of remote working benefits by an average of 2.392 points compared to the service sector. This is because manufacturing is not suitable for remote working. Even if some jobs allow work to be transferred to the home, the core part of manufacturing business must be carried out on company premises. This can create additional problems in managing a workforce, some members of which work from home while others are unable to take advantage of this option (see Table 5).

The domestic and international reach of a firm, compared to local/regional reach, also increases the benefits of remote working as perceived by managers This characteristic of a firm, together with its size, is likely to be related to the firm's competitive advantage, resources, and ability to absorb innovation [66].

An interesting finding concerns the amount of remote working that was done in companies before the pandemic and the effect this had on the perception of benefits. The mid-scale of remote working before COVID-19 reduces the benefits by an average of 6.078 points, compared to the small-scale of remote working. This finding runs counter to the theory of a firm's absorptive capacity, which is largely a function of the level of prior knowledge and experience and is central to firms' abilities to innovate [63,67]. Our research shows that the magnitude of perceived benefits may be greater in firms that are just discovering the potential of remote working implemented on a required basis, as opposed to firms that engage in remote work on a voluntary basis. This phenomenon can be interpreted not so much in the category of innovation leadership, but rather as a process of second-hand learning to catch up to innovator firms to remain competitive in a crisis environment [68]. In contrast, our research results show that a high proportion (over 60\%) 
of employees working from home negatively impacts the scale of benefits, reducing it by 6.18 compared to companies with up to $20 \%$ of employees working remotely.

Company support provided to employees in working from home, and monitoring the effects of remote working, are negatively correlated with the scale of perceived benefits, but they are not statistically significant. This finding is also surprising given that the first factor determining the success of teleworking is the support provided by the company and its supervisors [69]. That support encompasses not only help in performing duties, but also technical support [69]. The issue of monitoring has been less frequently discussed in the literature, but studies conducted during the pandemic show that monitoring was positively perceived by employees [4]. In our research, only the company's implementation of new IT tools to support remote working has a negative and statistically significant impact on the level of benefits, reducing it by 5.198 compared to entities that did not implement new IT solutions.

Turning to the analysis of factors affecting managers' perceptions of barriers to remote working during COVID-19, it can be concluded that, as with the benefits, statistically significant predictors of barriers include seniority, company size, industry, operational scope, frequency of remote working before COVID-19, number of employees working from home during the pandemic, and the implementation of new technological tools for remote working in a company. In addition, the evaluation of barriers to remote work is also influenced by a company's support for and its monitoring of the effects of remote work (see Table 6).

Table 6. Barriers to remote working, regression results.

\begin{tabular}{|c|c|c|c|c|c|}
\hline \multicolumn{2}{|r|}{ Variables } & \multirow{2}{*}{$\begin{array}{c}\text { Parameter } \\
\text { ref. } \\
0.869 \\
\end{array}$} & \multicolumn{2}{|c|}{$95 \%$ CI } & \multirow{2}{*}{$\begin{array}{c}p \\
0.227\end{array}$} \\
\hline Gender & $\begin{array}{c}\text { Man } \\
\text { Woman }\end{array}$ & & -0.536 & 2.274 & \\
\hline Seniority & $\begin{array}{l}6-15 \text { years } \\
\text { over } 15 \text { years }\end{array}$ & $\begin{array}{l}\text { ref. } \\
3.457\end{array}$ & 1.674 & 5.239 & $<0.001$ * \\
\hline Employees & $\begin{array}{c}\text { under } 50 \text { employees } \\
50-249 \text { employees } \\
\text { over } 250 \text { employees }\end{array}$ & $\begin{array}{l}\text { ref. } \\
3.41 \\
5.95\end{array}$ & $\begin{array}{l}1.521 \\
2.416\end{array}$ & $\begin{array}{c}5.3 \\
9.483\end{array}$ & $\begin{array}{l}0.001 * \\
0.001 *\end{array}$ \\
\hline Profile & $\begin{array}{c}\text { service companies } \\
\text { manufacturing companies }\end{array}$ & $\begin{array}{l}\text { ref. } \\
9.225\end{array}$ & 6.88 & 11.57 & $<0.001$ * \\
\hline Ownership & $\begin{array}{l}\text { Private } \\
\text { Public }\end{array}$ & $\begin{array}{l}\text { ref. } \\
4.03\end{array}$ & -0.085 & 8.146 & 0.056 \\
\hline Area & $\begin{array}{l}\text { Local/regional market } \\
\text { Domestic market } \\
\text { International market }\end{array}$ & $\begin{array}{c}\text { ref. } \\
-0.717 \\
-5.071\end{array}$ & $\begin{array}{l}-4.27 \\
-8.921\end{array}$ & $\begin{array}{c}2.836 \\
-1.221\end{array}$ & $\begin{array}{c}0.693 \\
0.011 *\end{array}$ \\
\hline Pre-COVID-19 & $\begin{array}{l}\text { Small-scale } \\
\text { Mid-scale }\end{array}$ & $\begin{array}{l}\text { ref. } \\
-4.13\end{array}$ & -6.323 & -1.937 & $<0.001$ * \\
\hline $\begin{array}{l}\text { Remote- } \\
\text { COVID-19 }\end{array}$ & $\begin{array}{c}\text { up to } 20 \% \\
21-60 \% \\
\text { Over } 60 \%\end{array}$ & $\begin{array}{c}\text { ref. } \\
-2.1 \\
-9.492\end{array}$ & $\begin{array}{l}-4.106 \\
-11.695\end{array}$ & $\begin{array}{l}-0.093 \\
-7.288\end{array}$ & $\begin{array}{l}0.042 \text { * } \\
<0.001 \text { * }\end{array}$ \\
\hline Support & $\begin{array}{l}\text { No } \\
\text { Yes }\end{array}$ & $\begin{array}{c}\text { ref. } \\
-6.623\end{array}$ & -9.31 & -3.935 & $<0.001 *$ \\
\hline Monitoring & $\begin{array}{l}\text { No } \\
\text { Yes }\end{array}$ & $\begin{array}{c}\text { ref. } \\
17.499\end{array}$ & 12.168 & 22.831 & $<0.001 *$ \\
\hline Technology & $\begin{array}{l}\text { No } \\
\text { Yes }\end{array}$ & $\begin{array}{l}\text { ref. } \\
-9.47\end{array}$ & -14.716 & -4.225 & $<0.001 *$ \\
\hline
\end{tabular}

* statistical significance $(p<0.05)$; Source: authors' own study.

Those managers with a longer tenure (more than 15 years) identified more benefits of remote working, as well as a larger number of barriers. The regression parameter for 
this variable is 3.457; therefore, it raises the level of barriers to remote work by an average of 3.457 points over the 6-15 year seniority. The implication is that experience shapes the evaluation of phenomena, perhaps causing them to be more realistic. Similarly, company size has a positive effect on perceived barriers: the larger the company, the greater the perception of the number of barriers to remote working, compared to the smaller enterprises (up to 50 employees). In addition, the fact that a company belongs to an industrial sector, which naturally limits the possibility of working from home, increases the number of barriers perceived.

With respect to the spatial extent of operations, only an international scope affects the perception of barriers, lowering it by an average of 5.071 points relative to local/regional extent. While the average scale of remote work before COVID-19 lowered the perceived benefits relative to the low frequency of remote work, the opposite was true for barriers. The moderate remote work scale before COVID-19 lowers the level of barriers by an average of 4.13 points relative to the low scale, which is consistent with the dependencies reported in the literature and the role played by experience. Moreover, the more extensively people worked from home during the pandemic, the lower the barriers they perceived. If the percentage of employees working remotely during the pandemic is between $21-60 \%$, that reduces the level of barriers to remote working by an average of 2.1 percentage points when compared with the percentage below $20 \%$, whereas if more than $60 \%$ of employees work remotely, the level of barriers decreases by an average of 9.492 percentage points when compared to the percentage below $20 \%$.

The impact of the three most important factors that are assumed to increase the effectiveness of working from home (i.e., support provided by the company, monitoring, and the implementation of IT tools that enable remote working) is mixed. As expected, remote work support received by employees lowers remote work barriers, by an average of 6.623 points. There is some evidence to support this claim in the literature. Haines et al. [33] found that remote workers report more positive outcomes when they experience broadbased support (supervisor support, technical support, and family support). The impact of monitoring on the scale of barriers to remote work is vastly different, raising it by an average of 17.499 points. Examples can be found in the literature to show the importance of adapting monitoring methods to the specifics of flexible work arrangements [1]. As Lautsch et al. [70] indicate, based on findings in the literature, managers must learn how to supervise, maintain contact with, and demand performance from subordinates who work from home. In doing so, supervisors must confront the increasing complexity of managing mixed workgroups when a company has some of the team working remotely and others working from the office [70]. Haphazard or unskillful monitoring can pose additional challenges for employees. The last factor examined, a company's implementation of IT tools supporting remote work, was consistent with expectations, lowering the level of barriers to remote work by 9.47 points on average.

\section{Conclusions}

As the intensive research done on remote working before 2020 shows, the benefits of and barriers to remote working vary, depending on the organization, the type of work, the employee's particular context, and the attitudes of supervisors, as well as on the specific circumstances and the remote working models that are used. The considerable research work done in this area to date, the difficulty in comparing results, and the lack of homogeneous conclusions pose challenges for both researchers and practitioners. The COVID-19 pandemic has disrupted not only social and economic life, but also the world of science. It has reoriented research, the findings of which are being confronted with a new reality, as evidenced by research on flexible working and remote working. The benefits and challenges of working from home, which has become a common experience for employees and organizations, is one of the emerging topics of this research. In addition, the questions of which companies have benefited most from remote working, and what scale of benefits 
has been achieved, depends on this research. Our research attempts to answer, at least in part, these questions.

This study contributes to the debate on the overall benefits and barriers of remote working, given the current pandemic challenges. The survey results presented in this article indicate that respondents appreciate the changes that have occurred at an accelerated pace in companies, especially in terms of adapting to radical change. The results positively assess the response when an organization moves part of its operational activity online and works to diversify products and services, indicating an increase in its flexibility. Managers also recognize the challenges that threaten a company's ability to adapt smoothly to the new reality. In particular, they recognize the lack of sufficient funds for investment, organizational preparation, and procedural preparation, and see the new working model as problematic. However, the overall assessment of the changes by organizations and managers is very positive. We conclude that the pandemic has accelerated the desired changes within organizations, which shows that companies have the capacity to adapt and develop and that crisis situations may give rise to positive changes [68].

Analyzing the level of benefits of remote working according to managers' ratings, it is clear that companies with more extensive experience with remote working before COVID-19 (pre-COVID-19 mid-scale) benefited less from the crisis than those with less experience prior to 2020 (pre-COVID-19 low-scale). Moreover, neither the support given to employees in relation to remote working by a company, nor the monitoring of remote working, affected the level of perceived benefits. The scale of perceived barriers to remote working was perceived to be lower when a company had more experience with remote working before the pandemic. The support of remote working by a company and the implementation of new IT tools to enable remote working reduce the barriers, while the monitoring of the effects of remote working increases them. These results suggest that the way a company and its employees are managed in a crisis, the approach of superiors to the evaluation and control of work effects, and the adaptation of support to the real needs of employees, all play fundamental roles. In short, the factors examined that influence the perceived benefits of or barriers to remote working from an organization's perspective contribute to adoption theory [71].

However, these findings require further in-depth research, as our study has some limitations. One limitation is that some of the independent variables were analyzed in a general way, without considering detailed dimensions, scales, or component levels. Therefore, it is recommended that in future studies some variables should be considered in more detail, e.g., the variable "Support" could be differentiated into "Daily" and "Weekly". Similarly, the variables "Monitoring" and "Technology" could be further differentiated to allow more detailed conclusions to be drawn. Another limitation was the inclusion of all companies that were interested in participating in the survey, without limiting the survey to the industrial or service sectors. In this study, industry was only one of the characteristics of the respondents. Future research could focus on one of the sectors to further explore the research problem, as the characteristics of the manufacturing and service industries are different.

In addition, our study does not include a detailed analysis of managers' work experience. Further identification of managers' responsibilities or seniority could shed more precise light on the results. For example, managers have different levels, such as senior and junior managers, and the advantages and disadvantages of remote working for managers at each level will be different. Depending on the level of a manager, the impact of different factors on the remote working environment may also be different. To explore these issues, qualitative research is needed to enrich these research findings. Furthermore, we focused on a general and quantitative capture of the benefits of and barriers to remote working during COVID-19, and the factors influencing their levels, but we did not provide for a qualitative assessment of companies' adaptation processes to the new circumstances. This will require attention in future research. In addition, studies are needed that analyze not only short-term outcomes but also long-term effects over years. It is necessary to conduct 
such future studies over a longer period of time to assess the factors identified in this study, as this could provide a much more comprehensive assessment of benefits and barriers.

Author Contributions: Conceptualization, M.U. and A.M.; methodology, A.M.; software, A.M.; validation, A.M. and H.W.-K.; formal analysis, A.M.; investigation, M.U.; resources, M.U.; writingoriginal draft preparation, A.M. and H.W.-K.; writing-review and editing, M.U.; visualization, A.M.; supervision, M.U.; project administration, M.U.; funding acquisition, M.U. All authors have read and agreed to the published version of the manuscript.

Funding: This work was supported by the Polish Ministry of Education and Science within the “Regional Initiative of Excellence" Program for 2019-2022. Project no.: 021/RID/2018/19. Total financing: PLN 11,897,131.40.

Institutional Review Board Statement: All the research procedures were compliant with the Code of Good Practices in HEIs developed by the Polish Rectors Foundation and adopted by the Plenary Meeting of the Conference of Rectors of Academic Schools in Poland (CRASP) on April 26, 2007 and with the ethical standards of the Cracow University of Economics adopted by the resolution of its Senate (no. 38/2011).

Informed Consent Statement: The survey was conducted in an anonymous form. The survey was placed on a paid, publicly available specialist portal webankieta.pl, which is a commercial and professional portal supporting survey research. No personal data was collected for the purposes of the survey. Participation in the survey was voluntary.

Data Availability Statement: Data are available on request.

Conflicts of Interest: The authors declare no conflict of interest.

\section{Appendix A}

Table A1. Specification of statements for building the synthetic measure "remote work benefit index" and their evaluation by respondents.

\begin{tabular}{|c|c|c|c|c|}
\hline No * & \multicolumn{2}{|c|}{ Statements } & $\begin{array}{c}\text { Structure of } \\
\text { Responses (\%) }\end{array}$ & $\begin{array}{l}\text { Rank (as Assessed } \\
\text { by Respondents) }\end{array}$ \\
\hline \multicolumn{4}{|c|}{ Remote Work Benefits } & \multirow{4}{*}{1} \\
\hline \multirow{3}{*}{ A1 } & Building a & definitely not & 0.43 & \\
\hline & flexible/learning & hard to say & 0.87 & \\
\hline & organisation & rather yes & 98.70 & \\
\hline & Diversification of & rather not & 8.70 & \multirow{2}{*}{3} \\
\hline $\mathrm{A} 2$ & services or products & rather yes & 91.30 & \\
\hline \multirow{4}{*}{ A3 } & Investments in IT & definitely not & 12.17 & \multirow{4}{*}{10} \\
\hline & infrastructure and & rather not & 14.35 & \\
\hline & solutions for remote & hard to say & 0.87 & \\
\hline & working & rather yes & 72.61 & \\
\hline \multirow{3}{*}{ A4 } & \multirow{3}{*}{$\begin{array}{l}\text { Moving some business } \\
\text { activities online }\end{array}$} & definitely not & 0.43 & \multirow{3}{*}{2} \\
\hline & & rather not & 3.48 & \\
\hline & & rather yes & 96.09 & \\
\hline \multirow{3}{*}{ A5 } & \multirow{3}{*}{$\begin{array}{l}\text { Increased R\&D } \\
\text { spending }\end{array}$} & definitely not & 9.57 & \multirow{3}{*}{5} \\
\hline & & rather not & 2.17 & \\
\hline & & rather yes & 88.26 & \\
\hline \multirow{4}{*}{ A6 } & \multirow{4}{*}{$\begin{array}{l}\text { Co-operating with } \\
\text { external entities on } \\
\text { innovation }\end{array}$} & definitely not & 13.48 & \multirow{4}{*}{7} \\
\hline & & rather not & 0.43 & \\
\hline & & hard to say & 0.87 & \\
\hline & & rather yes & 85.22 & \\
\hline \multirow{3}{*}{ A7 } & Training for employees & rather not & 10.00 & \multirow{3}{*}{4} \\
\hline & in advanced digital & hard to say & 11.30 & \\
\hline & technologies & rather yes & 78.70 & \\
\hline
\end{tabular}


Table A1. Cont.

\begin{tabular}{|c|c|c|c|c|}
\hline No * & \multicolumn{2}{|c|}{ Statements } & $\begin{array}{c}\text { Structure of } \\
\text { Responses (\%) }\end{array}$ & $\begin{array}{c}\text { Rank (as Assessed } \\
\text { by Respondents) }\end{array}$ \\
\hline \multicolumn{5}{|c|}{ Remote Work Benefits } \\
\hline A8 & $\begin{array}{c}\text { Creating new jobs based } \\
\text { on remote working } \\
\text { model }\end{array}$ & $\begin{array}{l}\text { definitely not } \\
\text { rather not } \\
\text { hard to say } \\
\text { rather yes }\end{array}$ & $\begin{array}{c}16.52 \\
0.43 \\
1.74 \\
81.30\end{array}$ & 8 \\
\hline A9 & $\begin{array}{c}\text { Increasing work } \\
\text { efficiency }\end{array}$ & $\begin{array}{l}\text { definitely not } \\
\text { rather not } \\
\text { hard to say } \\
\text { rather yes }\end{array}$ & $\begin{array}{c}16.96 \\
0.43 \\
2.17 \\
80.43\end{array}$ & 9 \\
\hline A10 & $\begin{array}{l}\text { Possibility to combine } \\
\text { professional work with } \\
\text { household } \\
\text { commitments }\end{array}$ & $\begin{array}{l}\text { definitely not } \\
\text { rather not } \\
\text { hard to say } \\
\text { rather yes }\end{array}$ & $\begin{array}{c}0.43 \\
16.08 \\
2.61 \\
80.87\end{array}$ & 6 \\
\hline
\end{tabular}

* Retained order of statements according to original survey form. Source: authors' own study.

\section{Appendix B}

Table A2. Specification of statements for building the synthetic measure "remote work barrier index" and their evaluation by respondents.

\begin{tabular}{|c|c|c|c|c|}
\hline No * & Statements & Structure of & nses (\%) & \multirow{2}{*}{$\begin{array}{c}\text { Rank (as Assessed } \\
\text { by Respondents) }\end{array}$} \\
\hline \multicolumn{4}{|c|}{ Remote Work Barriers } & \\
\hline B1 & $\begin{array}{l}\text { Insufficient IT } \\
\text { infrastructure }\end{array}$ & $\begin{array}{l}\text { definitely not } \\
\text { rather not } \\
\text { rather yes }\end{array}$ & $\begin{array}{c}13.91 \\
77.39 \\
8.70\end{array}$ & 6 \\
\hline B2 & $\begin{array}{l}\text { Shortage or lack of } \\
\text { computer hardware }\end{array}$ & $\begin{array}{l}\text { definitely not } \\
\text { rather not } \\
\text { rather yes }\end{array}$ & $\begin{array}{l}17.83 \\
73.91 \\
8.26\end{array}$ & 7 \\
\hline B3 & $\begin{array}{l}\text { Lack of ability to } \\
\text { perform certain duties } \\
\text { remotely due to limited } \\
\text { access to company } \\
\text { documents }\end{array}$ & $\begin{array}{l}\text { definitely not } \\
\text { rather not } \\
\text { hard to say } \\
\text { rather yes } \\
\text { definitely yes }\end{array}$ & $\begin{array}{c}27.39 \\
62.17 \\
0.43 \\
9.13 \\
0.87\end{array}$ & 8 \\
\hline B4 & $\begin{array}{l}\text { No possibility to work } \\
\text { remotely at some } \\
\text { workplaces }\end{array}$ & $\begin{array}{l}\text { definitely not } \\
\text { rather not } \\
\text { rather yes } \\
\text { definitely yes }\end{array}$ & $\begin{array}{c}30.00 \\
60.43 \\
8.70 \\
0.87\end{array}$ & 9 \\
\hline B5 & No safety procedures & $\begin{array}{l}\text { definitely not } \\
\text { rather not } \\
\text { hard to say } \\
\text { rather yes }\end{array}$ & $\begin{array}{c}28.70 \\
61.74 \\
0.43 \\
9.13\end{array}$ & 9 \\
\hline B6 & $\begin{array}{l}\text { Lack or limited funds } \\
\text { for investments }\end{array}$ & $\begin{array}{l}\text { definitely not } \\
\text { rather not } \\
\text { rather yes }\end{array}$ & $\begin{array}{l}14.78 \\
61.30 \\
23.91\end{array}$ & 1 \\
\hline B7 & $\begin{array}{c}\text { The need to prepare } \\
\text { instructions for } \\
\text { employees }\end{array}$ & $\begin{array}{l}\text { definitely not } \\
\text { rather not } \\
\text { hard to say } \\
\text { rather yes }\end{array}$ & $\begin{array}{c}12.17 \\
64.78 \\
6.96 \\
16.09\end{array}$ & 2 \\
\hline
\end{tabular}


Table A2. Cont.

\begin{tabular}{|c|c|c|c|c|}
\hline No * & Statements & Structure of & nses (\%) & \multirow{2}{*}{$\begin{array}{l}\text { Rank (as Assessed } \\
\text { by Respondents) }\end{array}$} \\
\hline \multicolumn{4}{|c|}{ Remote Work Barriers } & \\
\hline B8 & $\begin{array}{c}\text { Lack of transparency in } \\
\text { terms of work and } \\
\text { progress }\end{array}$ & $\begin{array}{l}\text { definitely not } \\
\text { rather not } \\
\text { hard to say } \\
\text { rather yes } \\
\text { definitely yes }\end{array}$ & $\begin{array}{c}30.00 \\
46.96 \\
13.48 \\
8.70 \\
0.87\end{array}$ & 6 \\
\hline B9 & $\begin{array}{c}\text { Reluctance of managers } \\
\text { or team leaders to work } \\
\text { remotely }\end{array}$ & $\begin{array}{l}\text { definitely not } \\
\text { rather not } \\
\text { rather yes }\end{array}$ & $\begin{array}{c}29.57 \\
60.86 \\
9.57\end{array}$ & 10 \\
\hline B10 & $\begin{array}{l}\text { Reluctance of } \\
\text { employees to work } \\
\text { remotely }\end{array}$ & $\begin{array}{l}\text { definitely not } \\
\text { rather not } \\
\text { rather yes }\end{array}$ & $\begin{array}{c}30.43 \\
60.43 \\
9.13\end{array}$ & 11 \\
\hline B11 & $\begin{array}{c}\text { Difficulties in } \\
\text { maintaining employee } \\
\text { efficiency }\end{array}$ & $\begin{array}{l}\text { definitely not } \\
\text { rather not } \\
\text { hard to say } \\
\text { rather yes }\end{array}$ & $\begin{array}{c}15.65 \\
72.17 \\
2.61 \\
9.57\end{array}$ & 3 \\
\hline B12 & $\begin{array}{l}\text { Decrease in employee } \\
\text { motivation and } \\
\text { commitment }\end{array}$ & $\begin{array}{l}\text { definitely not } \\
\text { rather not } \\
\text { rather yes }\end{array}$ & $\begin{array}{l}15.65 \\
74.35 \\
10.00\end{array}$ & 5 \\
\hline B13 & $\begin{array}{c}\text { Employees lack } \\
\text { sufficient digital skills }\end{array}$ & $\begin{array}{l}\text { definitely not } \\
\text { rather not } \\
\text { rather yes }\end{array}$ & $\begin{array}{l}14.78 \\
75.22 \\
10.00\end{array}$ & 4 \\
\hline B14 & $\begin{array}{l}\text { Internal communication } \\
\text { challenges }\end{array}$ & $\begin{array}{l}\text { definitely not } \\
\text { rather not } \\
\text { rather yes }\end{array}$ & $\begin{array}{l}16.52 \\
73.48 \\
10.00\end{array}$ & 6 \\
\hline
\end{tabular}

* Retained order of statements according to original survey form. Source: authors' own study.

\section{References}

1. Kurland, N.B.; Cooper, C.D. Manager control and employee isolation in telecommuting environments. J. High Technol. Manag. Res. 2002, 13, 107-126. [CrossRef]

2. Hodder, A.; Houghton, D.J. Unions, social media and young workers-Evidence from the UK. New Technol. Work Employ. 2020, 35, 40-59. [CrossRef]

3. De Sio, S.; Cedrone, F.; Nieto, H.; Lapteva, E.; Perri, R.; Greco, E.; Mucci, N.; Pacella, E.; Buomprisco, G. Telework and its effects on mental health during the COVID-19 lockdown. Eur. Rev. Med. Pharmacol. Sci. 2021, 25, 3914-3922. [CrossRef]

4. Wang, B.; Liu, Y.; Qian, J.; Parker, S.K. Achieving Effective Remote Working During the COVID-19 Pandemic: A Work Design Perspective. Appl. Psychol. 2021, 70, 16-59. [CrossRef] [PubMed]

5. Andriessen, J.H.E.; Vartiainen, M. (Eds.) Mobile Virtual Work. A New Paradigm? Springer: Berlin/Heidelberg, Germany, 2006.

6. Garrett, R.K.; Danziger, J.N. Which Telework? Defining and Testing a Taxonomy of Technology-Mediated Work at a Distance. Soc. Sci. Comput. Rev. 2007, 25, 27-47. [CrossRef]

7. European Commission. Telework in the EU before and after the COVID-19: Where We Were, Where We Head to; European Union: Brussels, Belgium, 2020.

8. Eurostat. Employed Persons Working from Home as a Percentage of the Total Employment, by Sex, Age and Professional Status (\%). Available online: https://appsso.eurostat.ec.europa.eu/nui/show.do?dataset=lfsa_ehomp (accessed on 7 August 2021).

9. Eurofund. New Forms of Employment; Publications Office of the European Union: Luxembourg, 2015.

10. Holtgrewe, U. New new technologies: The future and the present of work in information and communication technology. New Technol. Work Employ. 2014, 29, 9-24. [CrossRef]

11. Donnelly, N.; Proctor-Thomson, S.B. Disrupted work: Home-based teleworking $(\mathrm{HbTW})$ in the aftermath of a natural disaster. New Technol. Work Employ. 2015, 30, 47-61. [CrossRef]

12. Pérez, M.P.; Sánchez, A.M.; de Luis Carnicer, M.P. Top Manager and Institutional Effects on the Adoption of Innovations: The Case of Teleworking 1. Prometheus 2003, 21, 58-73. [CrossRef]

13. Scholefield, G.; Peel, S. Managers' attitudes to teleworking. N. Z. J. Employ. Relat. 2009, 34, 1-13.

14. Dimitrova, D. Controlling teleworkers: Supervision and flexibility revisited. New Technol. Work Employ. 2003, 18, 181-195. [CrossRef] 
15. Limburg, D.; Jackson, P.J. Teleworkflow: Supporting remote control with Workflow Management Systems. New Technol. Work Employ. 2007, 22, 146-167. [CrossRef]

16. Collins, A.M.; Hislop, D.; Cartwright, S. Social support in the workplace between teleworkers, office-based colleagues and supervisors. New Technol. Work Employ. 2016, 31, 161-175. [CrossRef]

17. Madsen, S.R. The Benefits, Challenges, and Implications of Teleworking: A Literature Review. Cult. Relig. Rev. J. 2011, 1, 148-158.

18. Nilles, J.M. Traffic reduction by telecommuting: A status review and selected bibliography. Transp. Res. Part A Gen. 1988, 22, 301-317. [CrossRef]

19. Nilles, J.M.; Carlson, F.R.; Gray, P.; Hanneman, G. Telecommuting-An Alternative to Urban Transportation Congestion. IEEE Trans. Syst. Man Cybern. 1976, SMC-6, 77-84. [CrossRef]

20. Mokhtarian, P.L. Telecommuting and travel: State of the practice, state of the art. Transportation 1991, 18, 319-342. [CrossRef]

21. Avery, C.; Zabel, D. The Flexible Workplace: A Sourcebook of Information and Research; Quorum Books: Westport, CT, USA, 2001.

22. Stephens, G.K.; Szajna, B. Perceptions and expectations: Why people choose a telecommuting work style. Int. J. Electron. Commer. 1998, 3, 70-85. [CrossRef]

23. Kurland, N.B.; Bailey, D.E. When workers are here, there, and everywhere: A discussion of the advantages and challenges of telework. Organ. Dyn. 1999, 28, 53-58. [CrossRef]

24. Harpaz, I. Advantages and disadvantages of telecommuting for the individual, organization and society. Work Study A J. Product. Sci. 2002, 51, 74-80. [CrossRef]

25. Ferreira, R.; Pereira, R.; Bianchi, I.S.; da Silva, M.M. Decision Factors for Remote Work Adoption: Advantages, Disadvantages, Driving Forces and Challenges. J. Open Innov. Technol. Mark. Complex. 2021, 7, 70. [CrossRef]

26. Jones, K. Going Home: New Technology's Impact on Remote Work Engagement. Adv. Bus. Res. 2010, 1, $168-175$.

27. Peters, P.; Tijdens, K.G.; Wetzels, C. Employees' opportunities, preferences, and practices in telecommuting adoption. Inf. Manag. 2004, 41, 469-482. [CrossRef]

28. Peters, P.; Ligthart, P.E.M.; Bardoel, A.; Poutsma, E. 'Fit' for telework? Cross-cultural variance and task-control explanations in organizations' formal telework practices. Int. J. Hum. Resour. Manag. 2016, 27, 2582-2603. [CrossRef]

29. Vilhelmson, B.; Thulin, E. Who and where are the flexible workers? Exploring the current diffusion of telework in Sweden. New Technol. Work Employ. 2016, 31, 77-96. [CrossRef]

30. Clark, E. Telecommuting and working from home. In IPCC 98. Contemporary Renaissance: Changing the Way we Communicate. Proceedings of the 1998 IEEE International Professional Communication Conference (Cat. No.98CH36332); IEEE: Quebec City, QC, Canada, 1998; pp. 21-25. [CrossRef]

31. Bailey, D.E.; Kurland, N.B. A review of telework research: Findings, new directions, and lessons for the study of modern work. J. Organ. Behav. 2002, 23, 383-400. [CrossRef]

32. Yap, C.S.; Tng, H. Factors associated with attitudes towards telecommuting. Inf. Manag. 1990, 19, 227-235. [CrossRef]

33. Haines, V.Y.; St-Onge, S.; Archambault, M. Environmental and Person Antecedents of Telecommuting Outcomes. J. Organ. End User Comput. 2002, 14, 32-50. [CrossRef]

34. Mello, J.A. Managing Telework Programs Effectively. Empl. Responsib. Rights J. 2007, 19, 247-261. [CrossRef]

35. Lebopo, C.M.; Seymour, L.F.; Knoesen, H. Explaining factors affecting telework adoption in South African organisations preCOVID-19. In Conference of the South African Institute of Computer Scientists and Information Technologists 2020 (SAICSIT '20); Association for Computing Machinery: New York, NY, USA; pp. 94-101. [CrossRef]

36. Baruch, Y. Teleworking: Benefits and pitfalls as perceived by professionals and managers. New Technol. Work Employ. 2000, 15, 34-49. [CrossRef]

37. Golden, T.D.; Veiga, J.F. The Impact of Extent of Telecommuting on Job Satisfaction: Resolving Inconsistent Findings. J. Manag. 2005, 31, 301-318. [CrossRef]

38. Fonner, K.L.; Roloff, M.E. Why Teleworkers are More Satisfied with Their Jobs than are Office-Based Workers: When Less Contact is Beneficial. J. Appl. Commun. Res. 2010, 38, 336-361. [CrossRef]

39. Wheatley, D. Good to be home? Time-use and satisfaction levels among home-based teleworkers. New Technol. Work Employ. 2012, 27, 224-241. [CrossRef]

40. Bellmann, L.; Hübler, O. Working from home, job satisfaction and work-life balance-robust or heterogeneous links? Int. J. Manpow. 2021, 42, 424-441. [CrossRef]

41. Brunelle, E.; Fortin, J.-A. Distance Makes the Heart Grow Fonder: An Examination of Teleworkers' and Office Workers' Job Satisfaction Through the Lens of Self-Determination Theory. SAGE Open 2021, 11, 2158244020985516. [CrossRef]

42. Maruyama, T.; Hopkinson, P.G.; James, P.W. A multivariate analysis of work-life balance outcomes from a large-scale telework programme. New Technol. Work Employ. 2009, 24, 76-88. [CrossRef]

43. Gálvez, A.; Martínez, M.J.; Pérez, C. Telework and Work-Life Balance: Some Dimensions for Organisational Change. J. Workplace Rights 2011, 16, 273-297. [CrossRef]

44. Gálvez, A.; Tirado, F.; Martínez, M.J. Work-Life Balance, Organizations and Social Sustainability: Analyzing Female Telework in Spain. Sustainability 2020, 12, 3567. [CrossRef]

45. Igeltjørn, A.; Habib, L. Homebased Telework as a Tool for Inclusion? A Literature Review of Telework, Disabilities and Work-Life Balance. In Universal Access in Human-Computer Interaction. Applications and Practice; Antona, M., Stephanidis, C., Eds.; Springer International Publishing: Cham, Switzerland, 2020; pp. 420-436. 
46. Palumbo, R. Let me go to the office! An investigation into the side effects of working from home on work-life balance. Int. J. Public Sect. Manag. 2020, 33, 771-790. [CrossRef]

47. Rodríguez-Modroño, P.; López-Igual, P. Job Quality and Work-Life Balance of Teleworkers. Int. J. Environ. Res. Public Health 2021, 18, 3239. [CrossRef]

48. Grant, C.A.; Wallace, L.M.; Spurgeon, P.C. An exploration of the psychological factors affecting remote e-worker's job effectiveness, well-being and work-life balance. Empl. Relat. 2013, 35, 527-546. [CrossRef]

49. Anderson, A.J.; Kaplan, S.A.; Vega, R.P. The impact of telework on emotional experience: When, and for whom, does telework improve daily affective well-being? Eur. J. Work Organ. Psychol. 2015, 24, 882-897. [CrossRef]

50. Reuschke, D. The subjective well-being of homeworkers across life domains. Environ. Plan. A Econ. Space 2019, 51, 1326-1349. [CrossRef]

51. Abendroth, A.-K.; Reimann, M. Telework and Work-Family Conflict across Workplaces: Investigating the Implications of WorkFamily-Supportive and High-Demand Workplace Cultures. In The Work-Family Interface: Spillover, Complications, and Challenges; (Contemporary Perspectives in Family Research, vol. 13); Blair, S.L., Obradović, J., Eds.; Emerald Publishing Limited: Bingley, UK, 2018; pp. 323-348.

52. Darouei, M.; Pluut, H. Work from home today for a better tomorrow! How working from home influences work-family conflict and employees' start of the next workday. Stress Health 2021, 37, 986-999. [CrossRef] [PubMed]

53. Ulucan, H. Relationship between Job Statisfaction Levels and Work-Family Conflicts of Physical Education Teachers. J. Educ. Learn. 2017, 6, 312-322. [CrossRef]

54. Ghislieri, C.; Molino, M.; Dolce, V.; Sanseverino, D.; Presutti, M. Work-family conflict during the COVID-19 pandemic: Teleworking of administrative and technical staff in healthcare. An Italian study. La Med. Del Lav. 2021, 112, 229-240. [CrossRef]

55. Chen, C.-F. Job satisfaction, organizational commitment, and flight attendants' turnover intentions: A note. J. Air Transp. Manag. 2006, 12, 274-276. [CrossRef]

56. Hill, E.J.; Ferris, M.; Märtinson, V. Does it matter where you work? A comparison of how three work venues (traditional office, virtual office, and home office) influence aspects of work and personal/family life. J. Vocat. Behav. 2003, 63, 220-241. [CrossRef]

57. Ellison, N.B. Social Impacts: New Perspectives on Telework. Soc. Sci. Comput. Rev. 1999, 17, 338-356. [CrossRef]

58. Teo, T.S.; Lim, V.K.; Wai, S.H. An Empirical Study of Attitudes Towards Teleworking among Information Technology (IT) Personnel. Int. J. Inf. Manag. 1998, 18, 329-343. [CrossRef]

59. Becurean, M. The impact of working from home on productivity. A study on the pandemic period. Ann. Univ. Oradea. Econ. Sci. 2020, 1, 267-275.

60. Nakrošienè, A.; Bučiūnienè, I.; Goštautaitè, B. Working from home: Characteristics and outcomes of telework. Int. J. Manpow. 2019, 40, 87-101. [CrossRef]

61. Perkins, W.S.; Rao, R.C. The Role of Experience in Information use and Decision Making by Marketing Managers. J. Mark. Res. 1990, 27, 1-10. [CrossRef]

62. Pulido-Martos, M.; Cortés-Denia, D.; Lopez-Zafra, E. Teleworking in Times of COVID-19: Effects on the Acquisition of Personal Resources. Front. Psychol. 2021, 12, 2485. [CrossRef] [PubMed]

63. Cohen, W.M.; Levinthal, D.A. Absorptive Capacity: A New Perspective on Learning and Innovation. Adm. Sci. Q. 1990, 35, 128-152. [CrossRef]

64. Griffy-Brown, C.; Nagamatsu, A.; Watanabe, C.; Zhu, B. Technology spillovers and economic vitality: An analysis of institutional flexibility in Japan with comparisons to the USA. Int. J. Technol. Manag. 2002, 23, 746-768. [CrossRef]

65. Pérez, M.P.; Sánchez, A.M.; de-Luis, P.; Jiménez, M. The Differences of Firm Resources and the Adoption of Teleworking Technovation 2005, 25, 1476-1483. [CrossRef]

66. Fosfuri, A.; Tribó, J.A. Exploring the Antecedents of Potential Absorptive Capacity and Its Impact on Innovation Performance. Omega 2008, 36, 173-187. [CrossRef]

67. Zahra, S.A.; George, G. Absorptive Capacity: A Review, Reconceptualization, and Extension. Acad. Manag. Rev. 2002, 27, 185-203. [CrossRef]

68. Kim, L. Crisis Construction and Organizational Learning: Capability Building in Catching-up at Hyundai Motor. Organ. Sci. 1998, 9, 506-521. [CrossRef]

69. Kowalski, B.K.; Swanson, J.A. Critical success factors in developing teleworking programs. Benchmarking: Int. J. 2005, 12, 236-249. [CrossRef]

70. Lautsch, B.A.; Kossek, E.E.; Eaton, S.C. Supervisory approaches and paradoxes in managing telecommuting implementation. Hum. Relat. 2009, 62, 795-827. [CrossRef]

71. Straub, E.T. Understanding Technology Adoption: Theory and Future Directions for Informal Learning. Rev. Educ. Res. 2009, 79, 625-649. [CrossRef] 